HStud 23 (2009)1, 121-145

DOI: 10.1556/HStud.23.2009.1.9

\title{
RECLAIMING THE STREETS - REDEFINING DEMOCRACY
}

\author{
THE POLITICS OF THE CRITICAL MASS BICYCLE MOVEMENT \\ IN BUDAPEST
}

\author{
ÉVA TESSZA UDVARHELYI \\ Graduate Center, City University of New York, New York \\ USA
}

\begin{abstract}
The Critical Mass bicycle movement, whose main aim is to reclaim cyclists' right to use city streets freely, safely and proudly, is arguably the single most powerful grassroots movement that has emerged in Hungary since the 1989 change of regimes. While Critical Mass is a critique of today's dominant motorized transportation practices as well as a celebration of alternative modes of transportation, it is not only about the environment. The Budapest Critical Mass can be read as the spatialized enactment of a direct and embodied form of democratic participation that goes beyond and at the same time transforms representative democracy. In the context of growing political apathy and widespread disillusionment with the formal public sphere in post-socialist Hungary, Critical Mass has emerged as a unique and powerful channel of citizen participation by forging a new kind of relationship between citizens, civil society and the state.
\end{abstract}

Keywords: Critical Mass, environmentalism, social movements, public space, political participation, embodiment, Hungary

City spaces reflect, organize and embody the categories, priorities and boundaries of urban society. As urbanist Michael Sorkin put it, "the city ... produces citizenship through the repetitive confrontation of citizens with an environment that organizes its prejudices and privileges physically" $(1999,7)$. The Critical Mass bicycle movement is one of the newly emerging social movements in Hungary that is consciously challenging the hegemonic physical and social norms governing today's urban environment. This movement is unique not only in the speed with which it has gained momentum but also in its ability to garner and maintain a strong grassroots constituency while exerting significant political impact. The Budapest Critical Mass is not only arguably the single most potent social movement that has emerged in Hungary since the change of regimes but it is also the largest - as both a movement and a ride - among the more than 200 Critical Masses organized in cities all over the world. 
This paper is based on two years of ethnographic research that I have done comparing the Critical Mass movements in New York and Budapest involving participant observation and formal and informal interviews. ${ }^{1}$ Even though that comparison offers intriguing insights, in this paper I am focusing on the case of Budapest alone. My research has been based on two complementary assumptions. First, that an examination of urban spatial practices reveals those social and political processes at work in a city that are often hidden from the eye and thus remain un-analyzed and naturalized. Second, that space is not simply a reflection of social, political, cultural and economic processes, but also plays a fundamental role in (re)producing these processes (Lefebvre, 1991). The purpose of my research has been to understand the ways in which urban public space is interpreted, contested and re-imagined in Budapest by participants in Critical Mass. Following in the footsteps of anthropologists and geographers such as Setha Low (1996), Michael Blomley (2001) and Don Mitchell (2003), I understand public space to be a spatial grounding of the public sphere. Through this lens, Critical Mass participants collectively imagine and perform active citizenship and re-define the relationship between citizens and the state. Critical Mass is a performance of political participation - all played out in the elaborate language and rituals of roads, bicycles, and traffic.

The specific features of the political opportunity structure (see della Porta, 1996) of post-socialist Budapest may partly account for the success of the movement in pressuring the city government for more bike-friendly policies. ${ }^{2}$ However, in this paper I have chosen to study the movement as a participant from within, in the tradition of an emic (Headland et al., 1990) approach by focusing on explanations provided by movement participants and organizers. ${ }^{3}$ Based on these interpretations, in the following, I will argue that the foremost significance of Critical Mass in Budapest is its contribution to the democratization of post-socialist Hungary by creating a unique space of political participation based on both an embodied experience of the city and a distinctive redefinition of both protest culture and civil society.

\section{Why Critical Mass? - A Personal Note}

With cycling as my main form of transportation since 2002 I have spent a great deal of time on city streets and roads, bike lanes and bike paths trying to get from place to place. It is not always easy. Riding a bicycle makes one more aware of social relations; it is a first-hand experience of exclusion and discrimination. But it is also an experience of strength, resilience and pride. While riding a bike, one cannot help but contemplate the dialectics of urban traffic, the violence embedded in 
a car-dominated city and the feeling of dignity that cycling in these conditions generates.

I took part in my first ever Budapest Critical Mass ride in April 2005 along with 20,000 other participants. My feelings were a combination of exhilaration and defiance: it was the first time after three years of riding my bicycle everyday to work, school and play that I felt I was not alone. I felt the power of the crowd - both its positive and negative power. I saw motorists shaking their fists angrily and scream obscenities as the thousands of cyclists passed by. I realized that the crowd that was so welcoming to me might seem threatening to others. Also, it was great to see people waving at us from their windows and pedestrians applauding this huge mass of happy cyclists. The ride ended with an ecstatic "bike-lift" with 20,000 cyclists lifting their bicycles above their heads, screaming with joy, relief and an incredible sense of power. It was a moment of euphoria I will never forget. Participating in Critical Mass has galvanized me for the 364 other days of the year. After this experience I knew that I had an invisible crowd behind and around me that dispelled my feelings of loneliness, isolation and weakness on the road. The term "empowerment" has become somewhat of a cliché. But it is still the best term to describe how I and many people feel about Critical Mass in Budapest. This movement has created an "us" from many isolated "I's". It makes us feel that we belong to a community. It has broken the invisibility of cyclists and made it impossible to ignore our presence and our needs on a number of different scales. And probably just as importantly, it has made us feel that we belong to the city - that we are not out of place anymore.

\section{Critical Mass as a Global Movement}

Critical Mass is a loose global movement ${ }^{4}$ that promotes regular bike rides in hundreds of cities worldwide. The movement was born in September 1992 with a mass bicycle ride organized in San Francisco then called "Commute Clot" meant to be partly a celebration of cycling as a form of everyday transportation and partly as a protest of the bad conditions and maltreatment urban cyclists had to endure on city streets (Ferrell, 2001, 105). The ride was later re-named Critical Mass after the documentary titled Return of the Scorcher that showed images of cyclists in China who, as one of the commentators of the film explained, in the absence of traffic signals managed to get their right of way at intersections by reaching a 'critical mass' that could easily push through car traffic (White, 2002, 148).

In its original form, Critical Mass questions not only the dominant power relations of the road by claiming a bigger share of it, but also challenges the dominant democratic practices of protest and political participation. Based on the anthology Critical Mass: Bicycling's Defiant Celebration, some of the main features of Crit- 
ical Mass as understood in the United States are that everyone participates for a different reason; there are no leaders; it occurs regularly (often on the last Friday of each month); routes are chosen collectively and spontaneously; it is highly decentralized in its "organization;" it is both a celebration and a protest; it is non-violent; and, finally, a major form of its organization is xerocracy (Carlsson, 2002). In most cities in the United States and many others worldwide, Critical Mass is considered an "organized coincidence" by its participants, so often no permit is sought from local authorities for holding the event. At times, this leads to confrontations with the police and shorter or longer periods of contentious relationship with the local authorities. ${ }^{6}$ However, being a decentralized and flexible global movement that is shaped most forcefully by local circumstances, needs and conventions, in each country Critical Mass rides acquire specific local features and some of the rides are even legally sanctioned and organized with a protest permit. In fact, one example that stands out in both its apparent compliance and lack of confrontation with the authorities and its distinctive local features is the Budapest Critical Mass.

\section{The Budapest Critical Mass}

The first Budapest Critical Mass occurred in 1998 when it was launched by a group called Friends of Urban Cycling (Városi Biciklizés Barátai) with inspiration from a Swiss urban planner interning at the Budapest City Hall. ${ }^{7}$ In many ways, these first rides followed the original model of Critical Mass very closely there was no press, no police permit and the event was spread by word of mouth. ${ }^{8}$ In a way, these rides attempted to replicate the original American rides as more of an "organized coincidence" than a movement with specific and well-defined aims. However, this first attempt at starting regular Critical Mass rides came to an end after a few successful occasions with between sixty and two hundred participants. ${ }^{9}$

The Budapest Critical Mass as we know it today was born in 2004. It was initiated by a collaboration between the Friends of Urban Cycling, other cycling advocacy groups and a group of bike messengers as "a protest against a statement of the mayor of Budapest. ... It was an official demonstration for a real car-free day." 10 The background to this "statement of the mayor" is explained by the following piece of news from 2004:

The City does not want to aggravate motorists so despite protests by bicycle organizations, it decided to organize the [Car Free Day] that every major European city holds next Wednesday in the middle of the rush hour, on a deserted Sunday afternoon. The City and the organizers think that motorists in Budapest would not yet be able to stand 
such a bicycle shock on a weekday. The cyclists will organize their own demonstration on Wednesday (Földes, 2004).

The alternative Car Free Day ${ }^{11}$ demonstration on September 22, 2004 drew around 4000 participants, which surprised even the organizers ${ }^{12}$ and indicated an existing need among Budapest cyclists for both more political recognition and improved physical infrastructure.

In a larger historical-political context, Critical Mass in Budapest is at the intersection of several social movement traditions. First, it is an indirect descendent of political-environmental movements in Hungary (e.g., the Danube Circle) and other Eastern European states that emerged in the 1980s as the first to challenge to the socialist system (see Pickvance, 2000). Second, Critical Mass stepped directly into the political and social space created by groups such as the Air Task Force (Levegő Munkacsoport) established in 1988, the Bike Task Force (Bringa Munkacsoport) established in 1992 and the Friends of Urban Cycling established in 1993.

Third, Critical Mass clearly represents the interests and aspirations of a distinct urban social group that emerged after the change of regimes: bike messengers. The first official Critical Mass was preceded by not only the regular monthly rides of the Friends of Urban Cycling or the so-called Black Rides (Fekete Tekerés) ${ }^{13}$ but the frequent and irregular rides organized by bicycle messengers such as the illegal night ride during the 2001 Cycle Messenger World Championship ${ }^{14}$ and illegal bike contests called alleycats among others. Bike messengers can be considered a new kind of urban proletariat (see Kidder, 2006) who are at the service of the fast-paced, service-oriented capitalist city. Bicycle messengers' working conditions, safety and lifestyle are intimately tied to the city. No wonder they have been at the forefront of struggles for bike infrastructure and cyclists' rights worldwide. In fact, the two people who became the main organizers of the Budapest Critical Mass are bike messengers who work at the very first bike messenger company in Budapest. ${ }^{15}$ Both of them clearly fit Marxist philosopher Gramsci's (1971) definition of "organic intellectuals" by representing the interests of a distinct social group while at the same time managing to attract allies from other social groups and classes - in this case mostly urban middle class youth. In this sense, Critical Mass exhibits many of the typical features of "new" social movements (della Porta - Diani, 1999) in that it is based less on class solidarity and more on cultural values and lifestyle choices. By all accounts, Critical Mass has managed to channel the amorphous, divergent and individualized needs of those who use cycling either for transportation or for employment into a more organized form of collective will - a truly grassroots social movement.

To some extent, Critical Mass resists a clear-cut definition as some of its most salient characteristics are flexibility, volatility and dynamism. However, when I 
asked my interviewees to define Critical Mass, they all agreed that its main goal is to popularize the bicycle as a means of everyday transportation on a mass scale. As one interviewee noted, "to put it simply, the goal of Critical Mass is to have as many people on bikes as possible". ${ }^{16}$ A more elaborate description of the movement is provided by another interviewee:

\begin{abstract}
Critical Mass is a bike ride that takes place twice a year, on Car Free Day and on Earth Day. And with this of course, I haven't even said one tenth of what Critical Mass is in reality. The protection and advocacy of cyclists' interests and the promotion and development of bike culture [such as using lights and understanding the difference between a bike lane and a bike path] is also part of it. It has many functions; practically all the functions that have to do with things that cyclists do both within their community and together as a community. ${ }^{17}$
\end{abstract}

While most outsiders would associate Critical Mass with the two big bike rides a year that attract tens of thousands of participants, for organizers, what takes place in between the rides is just as - if not more - important than the rides themselves. Over the years, Critical Mass has become a clearinghouse for "all things bicycle" in Hungary. Its website ${ }^{18}$ has become a major forum for the discussion of topics ranging from national bicycle policy to bicycle basics such as how to fix a flat tire (for a detailed description of the role of the website in organizing the movement, see Tordai, 2008). Over the past few years, a number of thematic rides have also been organized under the auspices of Critical Mass including the Tour de Voks, an effort to put cycling on the agenda of major political parties, Night Rides, which are more informal and adventurous, the so-called Last Fridays or Minimal Masses and the so-called Radical Mass among others. Finally, inspired by the success of the Budapest Critical Mass, since 2005 similar rides have been launched in several Hungarian towns by local activists, making the movement national in scope.

In terms of its organization, Critical Mass Budapest has a unique combination of a hierarchical and open structure. Based in my interviews and long-term observations, the best way to characterize the movement's organization is in concentric circles. At its core, the movement has five or six leaders who have complete decision-making power over issues such as the messages of the rides, press relations, organizational issues, website management etc. ${ }^{19}$ The presence of these leaders is what differentiates the Budapest Critical Mass from other Critical Masses all over the world and what partially gives it the character of a movement rather than a series of big bicycle rides. ${ }^{20}$ One of the leaders commented on this in the following way: "You can only start a mass movement if there are some people in charge, if there is somebody to follow. ... If you do this anonymously, you can only have a small movement." ${ }^{21}$ While the core leaders still retain their veto power, in 2009 around 25-30 core activists have been invited to become part of a wider deci- 
sion-making group that discusses strategic issues in an effort to cultivate the next generation of movement leaders. In the next layer of the circle are around 150-200 people who actively participate in discussions on the website and take responsibility for smaller projects such as thematic campaigns or specific rides. In terms of these smaller projects, questions of responsibility mostly depend on initiative rather than power differentials: whoever decides to take up an issue, topic or campaign will be responsible for it. Then, a group of around 300 people is made up of the so-called "organizers" or the "people wearing green T-shirts" who facilitate the two big annual rides. Many of them are veterans of Critical Mass and have participated in many previous rides; they play an essential role in making sure the two big annual events go smoothly and without major conflicts. A further layer of the concentric circle is represented by the many more thousand people who visit, read and post comments on the website (Tordai, 2008) that serves as an information and networking hub. While many of them do not or only sporadically take up specific active roles in the movement, their opinions and ideas still greatly influence the decisions of leaders and have an impact on the direction the movement is taking. Finally, there are the tens of thousands of cyclists who participate in the rides but might not even regularly visit the website and do not take up any active roles. Even though they are the most passive group, one of my interviewees pointed out their significance:

\begin{abstract}
And then, there are those who "only" go to the demonstrations, which is very important because the number of people on the ride is the most important measure of a demonstration. They are those who are biking, would like to bike, don't like the mayor or anything else; they have many different motivations such as being an environmentalist and other things. They are the ones who come, ride their bikes and have a good time. ${ }^{22}$
\end{abstract}

However, having thousands of people come to bike and have a good time serves a strategic purpose: the number of "average citizens" (as opposed to activists) participating in these rides is a constant reminder of the sheer size of the (political) constituency represented by Critical Mass as well as a basis for organizing a growing cyclist community.

In terms of the movement's achievements, in addition to mobilizing tens of thousands of people through the actual rides, by fostering open communication on the website, and offering various possible levels of engagement as well as many different smaller projects promoted by movement participants, it has bred hundreds of activists and smaller special interest volunteer groups related to all issues of cycling. Thus far, no other social movement or civil initiative has managed to produce such active participation and such high turnouts in Hungary. Critical Mass has also achieved real and measurable political impact. Over the years, the 
movement has managed to place cycling among the more prioritized issues of $\mathrm{Bu}-$ dapest's transportation policy, which has also been translated into concrete infrastructural improvements as well as a growing recognition of cyclists as a distinct urban user group. Clearly, the political establishment has realized the (voting) power of Critical Mass participants. As one leader stated metaphorically, "I am very rich. I have millions of forints invested in bike paths and bike lanes." ${ }^{23} \mathrm{Fi}-$ nally, it is undoubtedly thanks to Critical Mass that biking is no longer considered the sport of the freaks (as it was before Critical Mass started) and that Budapest is slowly becoming a biking city: every year the number of people who use their bikes regularly almost doubles (Index/MTI).

\section{The Embodied Politics of Critical Mass}

But, after all, what is it about Critical Mass, the bicycle or cycling that activates so many people? One of the main reasons, as I have found in my interviews, is that urban cycling offers a powerful experience of both politics and the city. Building on this experience, Critical Mass has created a uniquely embodied ${ }^{24}$ form of political involvement, which does not have deep traditions in Hungary, but still strongly resonates with many - especially young - people.

First, involvement in Critical Mass is heavily based on direct and personal experience: "this is a very personal cause". ${ }^{25}$ The people who are involved in Critical Mass all have a personal stake in the goals of the movement: they are not fighting for something far away from them. "Critical Mass is about myself. This is about me getting from point A to point B in a decent way." 26 In other words, Critical Mass is firmly rooted in the experience, needs and self-interest of a relatively large - and constantly growing - group of people. It is not fighting for lofty ideals or ideologies. As one interviewee put it,

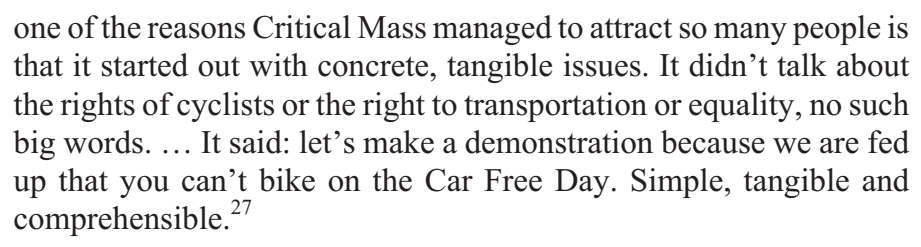
that it started out with concrete, tangible issues. It didn't talk about the rights of cyclists or the right to transportation or equality, no such big words. ... It said: let's make a demonstration because we are fed up that you can't bike on the Car Free Day. Simple, tangible and comprehensible. ${ }^{27}$

Second, the practice of cycling creates a strong identity not only because of all the subcultural elements associated with it (which some people share while others do not), but also because of the spatial experience of cycling. Today, the logic of urban mobility constantly reminds cyclists of their being "different" and "out of place", which is a very strong basis for group identity. The following account by 
an American cyclist - which could well take place in almost any big city in the world - describes how this message is continuously brought home:

When I started to use a bicycle as my primary source of transportation in the city, there were a lot of issues to contend with such as huge potholes, slotted curbside drainage gates, harsh winters, big hills, traffic speeding by on my left-hand side, and the constant threat of being smacked by a driver's side-door that is swung open without warning ("getting doored"). The more I rode, the more I became attuned to the fact that biking was still a great deal of fun, and also to the fact that most car drivers seemed like they did not want me on the street. Throughout my first year of commuting, I was consistently honked at, given dirty looks through windshields, almost run off the road, and had people yell things like, "get off the street!", "get a car!", and my personal favorite, "nice bike, faggot!" (Furness, 2005, xi).

In a similar vein, my Hungarian interviewees often described cyclists as a "minority" that needs protection. This feeling of minority status creates not only a strong sense of (in)justice but also a sense of community among activists, as illustrated by the following statement:

It's an awfully great feeling to join a team and to fight for a cause with others. It makes me so happy that we have been able to show that we also exist, that there is room for us on the roads of our country. ${ }^{28}$

Third, cycling is such a strong bodily experience that it often transforms a person's relationship to the physical and social aspects of the urban environment:

cycling is an exercise in geography - natural, social, cultural, political. As cyclists, we become intimately familiar with our network of public spaces, and with a city's terrain and its inhabitants (Switzky, 2002, 186).

Cycling in the city not only exposes the rider to elements of traffic and weather, but also creates a closer and more direct connection with the city's people and spaces. As one of my Hungarian interviewees put it, "when you bike, you realize how great a city can be. You start seeing and experiencing it from a completely different perspective. You see and feel things you haven't seen or felt before." ${ }^{29}$

Critical Mass not only magnifies and reinforces these elements of cycling, but adds a significant communal experience to it, which many people are clearly drawn to (and others, undoubtedly, are repelled by). ${ }^{30}$

When I saw the crowd [at the Critical Mass] I felt the same way the medieval troops must have felt when they saw the incredible size of 
the army at their destination, overwhelming and insurmountable, showing who is really in charge. At that moment, I felt invincible. ${ }^{31}$

Critical Mass is a way for cyclists to reconnect with the city, to re-occupy and take into ownership spaces they are otherwise denied. In fact, the most popular and effective pictures of Critical Mass are always those that show a completely transformed city - with cyclists completely filling up certain highly symbolic spaces -, an immanent utopia, or as participants and organizers usually put it, the image of "what Budapest will look like in 5 years". ${ }^{32}$ For example, it is only through Critical Mass that cyclists get to (legally) take bridges - in themselves highly symbolic spaces in Budapest - into full ownership by riding in the middle lanes and not on the sidewalk. Demonstrating the centrality of bridges in the re-conquest of the city, one of the most popular images of the April 2009 ride, for example, shows both lanes of Erzsébet Bridge jam packed with cyclists in all four lanes in both directions, a striking contrast to the more typical experience of thick lines of cars on the bridge stuck in traffic jams. In all, Critical Mass helps (re)establish a personal connection with the city. As one of my interviewees put it,

I love being a part of Critical Mass, I love going around on my bike and listening to music from the sound bike. Everywhere I see smiling faces. You go with the ride and you see different things everywhere, you see all parts of the city and this is really great. In this way, everybody makes the city their own. Everybody feels liberated when we bike in the middle of Deák tér [a centrally located and highly polluted square] or sunbathe in the middle of Ferenciek tere [another congested downtown square] where otherwise we would choke from the smog. 33

\section{Reclaiming the City}

During Critical Mass cyclists occupy center-stage, which is in sharp contrast to their everyday experience of spatial and social marginalization in the very same places of the city. As geographer David Sibley (1995) observes, occasions

\footnotetext{
when inversions assume a center-periphery form, when the dominant society is relegated to the spatial margins and oppressed minorities command the center, may represent a challenge to established power relations (44).
}

In this way, Critical Mass can be considered a struggle for what French sociologist Henri Lefebvre (1996) termed the "right to the city:" the right to inhabit and create a city based on human needs as opposed to the ideological and economic pressures of consumer capitalism. At a more theoretical level, when cyclists fight 
against the normalization of their inferior status on the road (and in urban policy in general), they are engaged in a struggle to turn city streets from what Lefebvre labeled as "abstract space" into "differential space" (Lefebvre, 1991). According to Lefebvre (1991), "abstract space tends towards homogeneity, towards the elimination of existing differences or peculiarities" (52) and is usually experienced as unquestionable. It is space that is produced by the "forces of the market" and backed up by apparently neutral "technical" considerations, which are largely alienated from everyday experience. Differential space, on the other hand, is based more on social practice than ideological considerations and aims to integrate difference, diversity and even conflict into the spatial experience. In this context, for many people, cycling is a way not only to re-appropriate but to re-humanize the abstract space of city. According to Michael Sorkin (1999)

propinquity - neighborliness - is the ground and problem of democracy [and] traffic is one medium through which this propinquity is engineered, the means by which different encounters are enabled and managed in the city (4-5).

As one Critical Mass organizer recounted in 2005:

\begin{abstract}
In '95 when I started cycling in the city center, most of us knew each other by face. Since then, the world has changed a lot: only this year the number of daily cyclists has doubled. But greetings are still in vogue. And it is particularly common when it rains. It's incredible that this still is happening in a city of two million people. All of a sudden, this makes it feel like a small village. If pedestrians started saying hello to each other, people would think they are crazy. And, of course, it is impossible to do same thing from a car. ${ }^{34}$
\end{abstract}

According to Lefebvre, modern urban planning practices have greatly contributed to the creation of abstract urban space that prioritizes order through the segregation and separation of activities, behaviors and social groups and sees the facilitation of smooth and fast traffic flow as its primary goal. It is in this way that the domination of individual motorized transportation is built into the logic of today's urban spaces and that facilitating traffic - which is mostly synonymous with car traffic - has become a technicality that professionals have to take care of and not something open to change or negotiable by citizens.

Today, the utmost principle of urban streets is flow: anything that obstructs traffic is to be removed and "the automobile system seeks invariably to exclude other modes that might come into conflict with it" (Sorkin, 1999, 10). Budapest is an archetypal example of this modernist urban space: at the moment it is unable to accommodate the differential uses of the street by not only cyclists but by pedestrians, people with disabilities, elderly and young people as well as those with baby strollers etc. In this logic of urban mobility, with their relatively slow speed 
and by being in places (e.g., roads) where they "do not belong" cyclists come to be seen as obstructing traffic. The institutionalization of this way of thinking is apparent in the practices and ideologies of Budapest urban and transportation planners, too:

It makes a difference how professionals relate to cycling, whether they identify with this cause or not. [...] When these professionals need to take up conflict, when it becomes obvious that some interests will be hurt, what appears in the final decisions is that the bicycle has no place here. [...] For these professionals, cyclists are a separate caste, a special group that stands apart from society and the norm. [...] They think that everybody has to be given the space they deserve and we cannot put driving in a disadvantaged position because of a tiny minority. 35

By reclaiming centrality and creating what Lefebvre $(1991,39)$ calls a space of representation Critical Mass aims to dispel the myth of the "tiny minority" and create physical, symbolic and political visibility and recognition: swarming city streets in the tens of thousands is a very direct and almost desperate attempt by cyclists at making themselves seen as part of the city.

Finally, in the midst of perpetual out-of-placeness and physical and symbolic violence, cycling tends to have a politicizing or radicalizing effect on many riders. There are different ways of channeling the frustration and anger that builds up as one tries to navigate their way in a place not made for them, and activism is definitely one of them. According to one of my interviewees:

practically, there is nobody among those who use their bike on a daily basis against whom no crime has been perpetrated. [...] When someone bikes a lot, after a while they will encounter something that makes them so outraged that they need to take action. Sooner or later he or she will start thinking in broader terms and start making connections. This is how many people become activists. ${ }^{36}$

In all, Critical Mass poses an embodied and experiential alternative to today's dominating abstract space and promotes a more personal and direct connection with the city. Much of the political strength of the Budapest Critical Mass is rooted in the powerfully embodied and personalized experience of urban cycling, which often leads to a questioning of the reification of the social and physical relations that dominate the city and brings about a desire to act collectively. 


\section{Reclaiming Protest}

Critical Mass is engaged in the construction of differential urban space in yet another way. Based on the movement's sensitivity to various forms and experiences of embodiment, it is using a wide variety of ways to define protest in order to reclaim both urban public space and the public sphere.

As noted above, traditionally, the Budapest Critical Mass takes place twice a year: on April 22 (Earth Day) and on September 22 (Car Free Day). While the 2004 ride had "only" 4,000 participants and went almost unnoticed by the press and the general public, participation in these events has been growing ever since with an all-time high in April, 2008 when an estimated 80,000 cyclists took part in

it. ${ }^{37}$ In the first years the rides had a well-planned route and were escorted both by the police and by hundreds of volunteers. However, the movement has undergone many changes since then and its volatile nature not only keeps the number of participants consistently high but also encourages participation. In fact, its various incarnations offer opportunities for very different (cycling) publics to engage in protest and express their needs and feelings as part of the same movement.

In order to differentiate between the two annual rides, in 2007, the organizers started calling the spring event the "festival" ride $^{38}$ and the fall event the "radical ride." With their sophisticated organization and friendly messages, the spring rides are extremely successfully at creating a safe and inclusive communal space for those with less experience on the bicycle. These are also the rides where huge numbers can be produced: neither politicians nor motorists can simply ignore a 50,000 or 80,000 -strong ride that blocks the city for almost an entire afternoon. The September Car-Free Day rides, on the other hand, did not only retain a more political and confrontational character but have even become bolder both in terms of their format and messages. The September 2008 ride that had the slogan "Transportation, not Demonstration" stands out among these: two venues were announced in advance, the starting point at Heroes' Square (Pest) and the end point on the other side of the Danube, Moszkva tér (Buda), but there was no set, permitted route in between the two points and participants were free to get from one square to the other taking whatever route they wanted. The goal was to shift away from the ritualistic demonstration of the past few years where participants were protected by closed off streets and to encourage both cyclists and motorists to use the city at the same time and interact with each other in a more or less regular traffic situation. While, the number of participants in this ride was estimated between five to ten thousand, organizers still considered it a great success. As one of them explained,

It would be a dead end street to create situations detached from the reality of life. [...] This day was an amazing experience for me. We were very brave to risk our good reputation and the big numbers by 
using Critical Mass as a tool instead of putting it behind an exhibition case. [Politicians] had better start getting ready now - the bicycle revolution will happen whether they want it or not. ${ }^{39}$

Quite different from both big annual rides are the so-called small Critical Mass, Minimal Mass or Last Friday rides. These have grown out of the need to have more regular and intimate rides and have been held on the last Friday of every month since October $2006 .{ }^{40}$ Importantly, the ride, which generally has from sixty to around a hundred participants, claims to be no demonstration: "This is a tour. If a tour bus doesn't need to ask for a permit, we don't need one either." ${ }^{\text {"11 }}$ Thus while the police are aware of the ride, no permit has ever been sought and the police have on occasion even escorted the ride. ${ }^{42}$ Also, even though riders claim no organizer, the rides follow a set route, which takes participants on bike routes and bike paths as well as city streets where these are not available. Although different people attend these rides for different reasons and it has no official goals, the ride definitely aims to make beginner cyclists feel comfortable on city streets, build community and create a fun group ride. In all, with both its more informal and diffuse aims and less confrontational spatial practices - by always taking the same route, using bike lanes and bike paths and respecting all traffic rules - these rides represent an approach to "protest" that is closest to everyday cycling and does not fundamentally question the status quo of the road.

As a final example, a so-called Radical Mass or "illegal" Critical Mass was held on both April 22nd 2008 (Tuesday) and April 22nd 2009 (Wednesday) after the Earth Day Critical Masses in both years were re-scheduled for a Sunday. ${ }^{43}$ While promoted on the main Critical Mass website and by many of the same people who are in charge of the big rides, the Radical Mass rides are aimed explicitly at a much smaller and more "hard core" audience of cyclists and wish to re-enact the spirit of the original San Francisco Critical Masses with no official police sanction, no pre-set route, no press coverage etc. While the ride goes wherever the people at its head take it, its route in both years has focused on major roads, thoroughfares and intersections in the central areas of both Pest and Buda including several bridges and the Tunnel. While it would be difficult - and probably also wrong - to assign a specific goal to these rides other than being a defiant and fun group ride, most participants love these rides for their freedom and, ostensibly, their almost provocative disrespect for some of the spoken and unspoken rules of the road and of protest (e.g., running red lights, taking up entire lanes, no request for permit, no appointed leaders) that the big Critical Masses take great pains to keep even when they try to imitate "transportation" instead of "demonstration." These rides are the most confrontational among all the manifestations of Critical Mass in their use of space as they go head-on against many traffic rules and exhibit much more defiance and stamina. The most obvious example of this stance is when participants stop in the middle of almost every intersection and perform the 
bike-lift followed by cheering and slogans such as "Every lane is a bike lane!"44 Unsurprisingly, this ride has attracted the most negative police attention: the first year, five riders were given summonses as witnesses to appear at the police precinct (the case was dropped, no charges were pressed) ${ }^{45}$ while the second year the police attempted to stop the ride (unsuccessfully), checked the identity cards of several participants and gave them summonses for traffic offenses (Földes, 2009).

Clearly, Critical Mass is much more than just two big rides every year. It is a multi-layered and multi-faceted grassroots movement with many different channels and forms of participation - both virtual and physical. With its various forms of protest, it embraces very different forms of political engagement and creates spaces for various people to feel at home in the movement. On the one hand, the Radical Critical Mass, represents what James Holston (1995) called insurgent citizenship. Similarly to its American counterparts, these rides are questioning basic structures of domination (such as the role of the police) and political participation (such as the practice of permitting protests). In this context, defying laws or traffic codes translates into a resistance against the hegemonic interests of motorized transportation - or, in more metaphorical terms - the hegemonic norms of living in and engaging with the structures of society. On the other hand, the big Critical Mass - both the Earth Day and Car Free Day rides - represents what I would call civic engagement, which is based on strategic interaction with the authorities and a respect for certain norms in order to achieve certain goals.

In all, by using variations on the same theme - biking en masse in urban traffic - Critical Mass upsets the naturalized order of the road and initiates a spatial dialogue about the logic of transportation, as well as the nature of both the city and protest, using a number of vernaculars. The movement creates what geographer Don Mitchell (1995) calls public space in a political sense. From this perspective, there are no inherently public spaces; without the enactment of contested meanings and uses, spaces are devoid of their public character. Spaces emerge as "public" only in and through action, struggle and contestation (Mitchell 1995, 115). While Critical Mass is contesting the inequalities and violence inscribed into Budapest's (transportation) spaces, at the same time it is acting out a new, differential and more integrated kind of public space. In this way, Critical Mass is giving substance to the idea of citizen participation by engaging in a variety of different spatial and political experiences to re-inhabit city spaces.

\section{Reclaiming Civil Society}

In addition to reclaiming the city for cyclists and redrawing the contours of protest culture, the final element that I have found in my interviews to be significant in Critical Mass's ability to mobilize and maintain such a large activist base is 
its efforts at carving out a unique and "authentic" space for citizen participation that does not necessarily fit current dominant ideas and practices of civil engagement. Briefly, in a country whose citizens have been more and more disappointed and repelled by mainstream politics since the transition from state socialism into capitalist democracy in the 1990s, Critical Mass seems to be creating an opportunity to act as a citizen without feeling that one is engaged in politicking.

The year 2005 brought a turning point in the relationship between Critical Mass and the Budapest city government. As one city official explained to me:

That year was a breakthrough: some people from Critical Mass walked into the office of the town clerk, talked to him and he had a moment of enlightenment - from that point on there has been a very strong expectation from above to speed up this bicycle issue. The civil initiative had a very significant role at that given moment. It might have arrived in half a year or a year, but they were the ones who ignited this new attention to cycling. ${ }^{46}$

Despite having gotten so close to the center of power, Critical Mass has managed to resist cooptation of any kind and keep its grassroots constituency throughout the years. Undoubtedly, boundary work has played a central role in this effort: two of the boundaries that Critical Mass is drawing the most forcefully are its separation from traditional politics on the one hand and the so-called third sector (see Anheier et al. 1990) on the other.

First of all, in an effort to create a new kind of space for political participation Critical Mass is challenging the extremely limited meaning of "politics" as well as the general overpoliticization of the public sphere in Hungary. Critical Mass leaders are very firm in that fundamentally, Critical Mass embodies hardcore (civil) politics. ${ }^{47}$ However, they take great pains to differentiate what politics denotes in the general discourse and what they mean by it. As one participant put it,

it is always very difficult but we manage to keep politics away from Critical Mass. We don't want politics to take over. By politics I mean what goes on in Hungary at large ${ }^{48}$ - because what we are doing is also heavily political. ${ }^{49}$

One participant articulated Critical Mass's old-new definition of politics very succinctly when he pointed out that: "in its original sense, politics means dealing with public affairs. ... And this is the kind of politics that Critical Mass engages in. ${ }^{, 50}$ In other words, Critical Mass is trying to create a kind of civil society that influences political society (see Gramsci, 1971) but is neither drowned in nor co-opted by it.

The absence of ideologies is central to this endeavor and core organizers agree that there is no universal political truth from the point of view of Critical Mass. ${ }^{51}$ The integration of many different kinds of people - similarly to the different 
forms of spatial re-appropriation Critical Mass is using - is also key to the movement's success:

Hungary has become so polarized that everybody needs to be something: rightist, leftist, Gypsy, Jew, this or that. People hate that. They can't take part in anything anymore. But there is an inner drive for people to be together. They need the communal experience, they need to belong to a community. [...] Critical Mass is the only place where $[\ldots]$ there is no polarization. In the same crowd there all kinds of extremists and they don't even know about each other. This is why it has become so big in Budapest. ${ }^{52}$

Critical Mass is so firm in keeping its doors shut to anything that does not fit its definition of "civic" that unlike many environmental movements all over the world, it is trying to keep a distance even from (alternative) parties that clearly define themselves as both grassroots and green. For example, participants of the movement were very critical of a newly formed party-coalition with a strong environmental and social platform (as well as overlapping membership) when its activists were soliciting recommendations for the upcoming European elections at the April 2009 Earth Day Critical Mass ride. Even though this party is definitely not part of the traditional political elite and it is the only party that takes cycling seriously as part of their environmental policy proposals, their presence at the ride caused considerable tension within the movement. This incident shows the firmness of the movement's boundaries when it comes to any kind of contact with what is perceived as the traditional realm of politics.

As for the vision of the movement regarding social change, movement leaders do not have illusions about the mechanism of political power. Taking the name of the movement as seriously as possible, their main strategy is to create a critical mass of people who are biking in the city so that their needs and voices are impossible for politicians and city officials to ignore. As the two main leaders of the movement explained, the movement is challenging the system at its weakest: the citizens themselves. ${ }^{53}$ It is not targeting the state directly. It is keeping an eye on it, following its actions and even organizing around them, but the focus of organization is to radically raise the number of cyclists, which - given the fundamentally personal and embodied politics of cycling - is also a way to create more engaged citizens. The political agenda of Critical Mass is based on the recognition that the urban environment is produced by political and economic forces that are not outside of human will and action and that the main reason there is no room for cyclists on the road is because no room has been made for them. But if the necessary amount of people pushes hard enough, as in the case of the Chinese intersection that inspired the name of the global movement, urban space will be re-shaped so that it can accommodate their presence and needs as well. The basis of the politics 
of Critical Mass is that people - and not bureaucracies or even the "rules" of transportation - make both places and politics. As one participant put it,

Many people think that in other places the bike infrastructure just appeared out of nowhere. It is not true. In Amsterdam it was called White Bicycle. There was a movement there, people who believed in this, who said that this is a good idea and pushed for it. [...] These things didn't just happen. People made them happen. ${ }^{54}$

In addition to distancing itself from mainstream politics, Critical Mass is drawing a second very clear boundary between itself and official NGOs. In my interviews several participants talked about their disappointment with the power struggles and formalities within official NGOs as well as with the compromises they are forced to make for the sake of survival. Many people seem to join Critical Mass exactly because it promises a different path. In an interview, one of the leaders of the movement expressed this stance in the following way:

Critical Mass is the only civil organization in this country that works like a civil organization. It is grassroots and there is no money involved - we never got, never asked for and will never ask for money. ${ }^{55}$ We never write grants, we have nothing and we will not have anything. The only thing we have is a mass basis. I find those civil initiatives outrageous where there is a good grant writer and they decide what they are going to do with the money only after they got it. How can you get money from the same place that you are trying to go against? ${ }^{56}$

Similarly to politics, civil society has also acquired many negative connotations in Hungarian public discourse. With many of the NGOs formed after the change of regimes focusing on individual rather than collective empowerment (Larsson, 2004), distancing themselves entirely from the public sphere or following trends set by government and European Union grants, the post-socialist traditions of movement building are relatively weak. ${ }^{57}$ With the bicycle as both personal and apparently apolitical, Critical Mass has been able to form a movement that creates an advantage out of not conforming to the image of the passive and even somewhat corrupted third sector organizations.

Critical Mass has many legs. You can be one of its legs but if you step out for a moment, the whole thing won't fall over as there are millions of other legs holding it up. It is a little bit like a very ideal social system - one that sociologists are dreaming about - a real civil thing. Everybody sees their own perspective, but they also see something of the whole. It is possible that these perspectives are total opposites of each other, but they are still pulsating and fertilizing the whole thing and it works. This is awesome. This is a quintessentially civil initia- 
tive, with the largest and coolest mass basis and the most effective in the long run. ${ }^{58}$

Finally, one of the most effective ways Critical Mass has found to draw and maintain its boundaries with politics and the NGO sector without losing power is to facilitate the birth of a new cycling advocacy organization. The group called Hungarian Cycling Club (Magyar Kerékpárosklub) uses the political clout created by Critical Mass but works independently from it. In 2005 exactly at the moment when Critical Mass was first acknowledged by City Hall as a potent political force and got its first serious promises for significant improvements in the city's bicycle infrastructure, the Hungarian Cycling Club took over all the lobbying work from Critical Mass. Its staff and volunteers (most of them activists in Critical Mass, too) do everything that Critical Mass would never want to engage in for fear of having to make a compromise or selling out: they attend meetings with politicians and representatives of City Hall; they write grants; they attend international conferences and they make official public statements. The Cycling Club takes the pressure of political navigation off of Critical Mass by not only being a more conventional NGO but also by taking conventional politics more seriously. As the head of the Cycling Club put it,

\begin{abstract}
We cannot afford the luxury to create a situation where there is no way out for our partners, where they feel cornered. We can't afford to shut the door and leave, because then we will have no results. We need to produce results. We never make trouble. We say less or more strongly what we want and we say it as long as we achieve what we want. [...] Critical Mass can say anything, they can curse the government as loudly as they want, but we cannot do that. We are partners. ${ }^{59}$
\end{abstract}

In fact, this "professionalism" and partnership between the Cycling Club, City Hall and the relevant Ministries is one of the things that ensures the continued "innocence" and firmly grassroots nature of Critical Mass, which is not unprecedented but very unique in Hungarian civil society.

\title{
Conclusion and Dilemmas
}

As I have shown in this paper, Critical Mass in Hungary plays a very unique role in creating a forum for political participation in a society where despite their alienation from the political class and disappointment with politics in general, citizens are craving democratic participation. Critical Mass fills up this vacuum for many people: it works because it is based on real needs and aspirations and because it has no identifiable party political or ideological identification. One participant summed up this achievement in the following way: 
I can feel the potential in Critical Mass, that we can change things. [...] The ailment of Hungarian democracy is that people see themselves as separate from it. People are outraged at how the politicians are, how the roads are, how everything is, and they feel they don't have anything to do with that. They feel like they are not even a part of it: it is awful how politicians are but I have no role in this story. [...] It's not true. I am also part of the big whole. And then comes the question: what have I done for this whole thing? ${ }^{60}$

Critical Mass's greatest contribution to the democratization of post-socialist Hungary is to break passivity, educate a new generation of active citizens and redefine civil engagement in widely accessible terms. Framing itself as movement "only about biking" makes it is easier for many people to connect and participate. However, this is also a highly ambiguous path and movement's future poses a number of dilemmas. In a country with serious social and economic problems, why is the strongest movement organized around biking? Does Critical Mass foster citizen participation in general or is biking the smallest possible common denominator? How far can the political tolerance of Critical Mass stretch in terms of accepting all worldviews, orientations and ideologies including those of the far right as long as "only" biking is at stake? Do Critical Mass participants see the broader implications of their fight for the right to the city? Would they be willing to form alliances with groups very different from them such as the Roma, the homeless or immigrants whose exclusion, discrimination and oppression occurs on a much larger scale? Would it be possible to apply the mobilization strategies of Critical Mass to launch movements around other pressing issues or they only work for this particular issue? One participant's musings reflect these inherent dilemmas well:

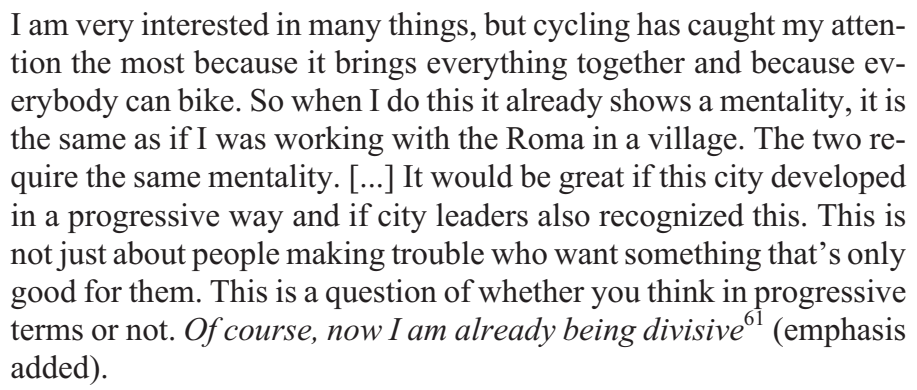
the same as if I was working with the Roma in a village. The two require the same mentality. [...] It would be great if this city developed in a progressive way and if city leaders also recognized this. This is not just about people making trouble who want something that's only good for them. This is a question of whether you think in progressive terms or not. Of course, now I am already being divisive ${ }^{61}$ (emphasis added).

Critical Mass is a revolt not only against the fetishization of the automobile, the consumer culture it is embedded in and the skewed public and transportation spaces these produce but also against the indifference and passivity of Hungarian society. As such, it is an extremely significant protest initiative. However, the question still remains as to where Critical Mass's rejection of any kind of value judgment or ideological-political orientation will take it. Why is being progres- 
sive seen as divisive, as my interviewee above has indicated? Is it possible for a social movement to strip itself of any and all values other than a love for biking without falling into the trap of technicalities or very narrowly defined self-interests? A close examination of the development of both Critical Mass and Hungarian democracy in the next few years will provide us with some of the answers to these questions.

\section{Acknowledgements}

First and foremost, I would like to thank all of my interviewees - most importantly the participants and organizers of the Budapest Critical Mass as well as officials at the Budapest City Hall - for participating in my research project and giving me some of their precious time. Their insights have been incredibly useful and inspiring. I would also like to thank my fellow graduate students and professors at the Graduate Center of the City University of New York for their helpful comments on earlier versions on this paper, my advisor Professor Setha Low for her continuous support and helpful insights, Liane Nikitovich for her help with editing, as well as my parents for their truly constructive critique of this paper. Finally, I would like to thank Ágnes Fülemile for inviting me to present at the Landscape, Environment and Society: Environmental Issues in Hungary Past and Present conference in Bloomington, Indiana and the journal for the opportunity to publish this paper.

Notes

1

The interview excerpts and quotes in the text come from 20 interviews I conducted with organizers and participants of the Budapest Critical Mass as well as representatives of the Budapest Police Department and the Budapest City Hall between the winter of 2008 and the spring of 2009. Most interviews took place in person, while some were conducted over email. The interviews lasted about 1.5 to 2.5 hours. Interviewees were selected with snowball-sampling until theoretical saturation (Strauss 2008) was achieved. In addition to the interviews, some of the quotes in this paper come from the publicly available www.criticalmass.hu website. All of the interviewees have signed consent forms promising them anonymity.

2 The fact that Budapest has had a liberal mayor for 20 years whose political sympathies - at least at the level of rhetoric - are with progressive causes has certainly had a role in creating a welcoming or at least tolerant political environment for Critical Mass to have significant practical achievements in such a short span of time.

3 My position throughout this research was that of an engaged researcher or "citizen anthropologist" (see Tax 1964) and in no way did I try to conform to the myth of the "disinterested researcher." I see my role as a passionate critic whose mission is to use various frames of understanding including personal participation, fieldwork and theoretical insights by relevant au- 
thors to provide a kind of analysis that helps members of the movement reflect on themselves and grow as a collective.

4 Although Critical Mass has been described on various occasions as a movement (see for example Blickstein et al 2001), one of the main features of Critical Mass is that participants "have been successful in their ability to resist external definition, classification, or reduction by creating independent, autonomous, non-hierarchical groups of riders throughout the world" (Furness 2005, 89).

5 Xerocracy is defined as the spreading of ideas by Xeroxing them on fliers, posters etc. (Carlsson 2002).

6 In the United States, famous cases of usually unwarranted and violent police crackdowns on Critical Mass rides include those in San Francisco, Minneapolis, Austin and New York City (for more on this see Blickstein 2008; Carlsson 2002).

7 Interview, Budapest Department of Transportation, 09.26.2008

8 Email interview, 09.29.2008

9 Email interview, 09.28.2009

10 Blog posting by Kuku 09.26.2008. http://criticalmass.hu/blogbejegyzes/20080925/levelnew-york-i-cm-tol. Author's translation.

11 Among other things, the issue of Car Free Days has remained an important framing device for the movement. In 2005, after a 10,000-strong Earth Day Critical Mass in April, the City decided to close down Andrássy út, one of the major thoroughfares of the city on Thursday, September 22, signaling a growing (symbolic) commitment to the cause of cycling. From then on, the City has always made a point of closing off Andrássy út on September 22nd, the actual day of Car Free Day, regardless of whether it was on a weekday or a weekend. In this way, Car Free Day was transformed from a mere bureaucratic gesture into a meaningful event as well as a powerful platform for both community participation and community input for cyclists.

12 Interview, Szóda Café, 01.14.2008

13 Organized since 2002 in memory of cyclists killed on the road and to promote a better understanding between motorists and cyclists.

14 Interview, Szóda Café, 01.14.2008

15 Called Hajtás Pajtás, also established in 1993.

16 Interview, Gödör Klub, 07.10.2008. Author's translation.

17 Interview, Millenáris Velodrom, 07.23.2008. Author's translation.

18 www.criticalmass.hu

19 The general public identifies two people as the main organizing figures of the ride, but they insist that from the beginning of the movement there has been a group of 5-6 people who are not as visible but have just as important a role in all decisions regarding the movement.

20 In New York City, for example, great emphasis is placed on the leaderlessness of Critical Mass in both rhetoric and practice: „It is a leaderless ride, free and open to all, where bicyclists take to the streets to promote bicycling as the best means of urban transit. ... Critical Mass is a bike ride, not an organization, and no two riders participate for exactly the same reason" (What is Critical Mass? Electronic document, accessed from http://times-up.org/index.php?page=critical-mass-what).

21 Interview, Hunyadi tér, 09.24.2008. Author's translation.

22 Interview, Millenáris Velodrom, 07.23.2008. Author's translation.

23 Interview, Szóda Café, 2008.01.14 Author's translation. See also blog posting by Kuku 11.29.2006, accessed from http://criticalmass.hu/blogbejegyzes/20061129/hogyan-legyelmilliomos-nehany-ora-alatt-a-critical-mass-el

24 I use embodiment or embodied politics in a variety of interlocking senses including the intense physical-sensory experience of cycling in the city, the feminist understanding of the personal 
as political, the performative nature of subversive politics (see Martin 1990), the inscription of power and spatial relations on the body of cyclists (see Douglas 1996) as well as in the sense of embodied space as "the location where human experience and consciousness take on material and spatial form" (Low 2003, 10).

25 Interview, Millenáris Velodrom, 07.23.2008. Author's translation.

26 Interview, New York City, 05.10.2008. Author's translation.

27 Interview, Millenáris Velodrom, 07.23.2008. Author's translation.

28 Blog posting by Virus 04.21.2008, accessed from http://criticalmass.hu/blogbejegyzes/ 20080420/mit-jelent-szamodra-critical-mass-elmenybeszamolokat-keresek. Author's translation.

29 Interview, Gödör Klub, 09.24.2008. Author's translation.

30 Over the past few years, I have heard more and more avid cyclists (both commuters and bike messengers) complain about the size of the crowd and the impossibility of getting ahead on the ride. As participation in the Mass is becoming less and less crucial because of obvious significant public support, some people in the biking community support the movement but do not actually participate in the rides.

31 Blog posting by Dogfish 04.21.2008, accessed from http://criticalmass.hu/blogbejegyzes/ 20080420/mit-jelent-szamodra-critical-mass-elmenybeszamolokat-keresek

32 Interview, Hunyadi tér, 09.24.2008. Author's translation.

33 Interview, Gödör Klub, 09.24.2008. Author's translation.

34 Blog posting by Kuku 12.22.2005, accessed from http://www.criticalmass.hu/blog/ 20050922/koszonjunk

35 Budapest Department of Transportation. 09.26.2008. Author's translation.

36 Interview, Millenáris Velodrom, 07.23.2008. Author's translation.

37 The exact number of participants in Critical Mass has been an object of debate from the very beginning as neither the authorities nor organizers are able to produce exact numbers, only estimates. 80,000 is the number usually publicized about this ride, some estimate that the actual number of participants must have not exceeded 20,000 - which is still a huge number for any demonstration in Budapest.

38 They also often call it a "majális" or May Day ride referring to the family and consumption-oriented tradition of celebrating Labor Day during and even after the socialist regime in Hungary.

39 Blog posting by Kuku 09.23.2009, accessed from http://www.criticalmass.hu/blogbejegyzes/ 20080923/koszonet-es-egy-kis-ertekeles

40 Interview, Gödör Klub, 07.10.2008. That year, the Car Free Day Critical Mass was cancelled due to violent riots in Budapest.

41 Interview, Gödör Klub, 07.10.2008. Interview, Millenáris Velodrom, 2008.07.23. Author’s translation.

42 Interview, Gödör Klub, 07.10.2008

43 This has been criticized by some as replicating the mayor's earlier decision to postpone the Car Free Day. However, by putting this ride in the context of the whole movement, the organizers attribute strategic significance to being flexible enough with the dates in order to be able to accommodate a variety of different audiences and interests.

44 This is the Hungarian version of the original slogan "Share the Road!"

45 Blog posting by ubi 06.27.2008, accessed from http://criticalmass.hu/blogbejegyzes/ 20080627/biciklis-szabalysertes-fold-napjan-tanuk-meghallgatasa

46 Budapest Department of Transportation. 09.26.2008. Author's translation.

47 Interview, Szóda Café, 01.14.2008 
48 My interviewee here was referring to the continuous bickering between major political parties in the Parliament and through the media.

49 Interview, Gödör Klub, 09.24.2008. Author's translation.

50 Interview, Millenáris Velodrom, 07.23.2008. Author's translation.

51 I concluded this from a series of discussions that took place in April 2009 on the mailing list of core organizers preceding the Earth Day Critical Mass ride of that year when a number of different organizations including some legal advocacy groups asked to be represented at the ride and organizers decided to turn them down.

52 Interview, Pasaréti tér, 09.25.2008. Author's translation.

53 Interview, Szóda Café, 01.14.2008

54 Interview, Gödör Klub, 09.24.2008. Author's translation.

55 The expenses of Critical Mass (e.g., the production of stickers and other PR materials) are covered by private donations as well as from the sale of commemorating T-shirts for each year's ride.

56 Tömegbázis és hitelesség (Mass basis and credibility). Video, accessed from http://www. legrovidebbut.hu/szemelyes-galleria/content/tomegbazis-es-hitelesseg

57 While movements of the radical right are emerging as powerful actors in the public sphere, some of the more successful progressive grassroots social movements formed since the change of regimes include the Humanist Movement and the broader environmental movement, although neither is able to mobilize such a mass basis as Critical Mass.

58 Interview, Gödör Klub, 09.25.2008. Author's translation.

59 Interview, Pasaréti tér, 09.25.2008. Author's translation.

60 Interview, Gödör Klub, 09.25.2008. Author's translation.

61 Interview, Gödör Klub, 09.24.2008. Author's translation.

\section{References}

Anheier, H. K. - Seibel, W. (eds) (1990) The Third Sector: Comparative Studies of Nonprofit Organizations (Berlin-New York: Walter de Gruyter).

Blickstein, S. - Hanson, S. (2001) 'Critical Mass: Forging a Politics of Sustainable Mobility in the Information Age', Transportation, Vol. 28, No. 4, 347-362.

Blickstein, S. (2008) 'Critical Mass: Bicycling Towards a More Sustainable City' (Dissertation for Clark University, Manuscript).

Blomley, N. (2001) 'Introduction', in N. Blomley, D. Delaney and R. T. Ford (eds) The Legal Geographies Reader (Oxford: Blackwell). 3-5.

Carlsson, C. (ed.) (2002) Critical Mass: Bicycling's Defiant Celebration (Edinburgh: AK Press).

Douglas, M. (1996) Natural Symbols: Explorations in Cosmology (New York: Pantheon Books).

Ferrell, J. (2001) Tearing Down the Streets. Adventures in Urban Anarchy (New York: Palgrave).

Földes, A. (September 17, 2004) ‘Demszky vasárnap, Persányi szerdán teker’ (Electronic document accessed from http://index.hu/kultur/eletmod/amn0917/ on May 15, 2009).

Földes, A. (April 24, 2009) Szabálysértési ügyek indulnak az illegális CM miatt (Electronic document, accessed from http://kerekagy.blog.hu/2009/04/24/szabalysertesi_ugyek_indulnak_az _illegalis_cm_miatt on May 15, 2009).

Furness, Z. M. (2005) 'Put the Fun Between Your Legs!', The Politics of Counterculture of the bicycle (Manuscript) (Accessed from etd.library.pitt.edu/ETD/available/etd-12052005-210916/unrestricted/Z.Furness2005.pdf on May 15, 2009).

Gramsci, A. (1971) Selections from the Prison Notebooks (New York: International Publishers). 
Headland, T. N., Pike, K. - Harris, M. (1990) Emics and Ethics. The Insider/Outsider Debate (Newbury Park: Sage).

Holston, J. (1995) 'Spaces of Insurgent Citizenship', Planning Theory, Vol. 13, 35-51.

Index/MTI (September 22, 2007) 'Bicikliseké és motorosoké lett Budapest' (Electronic document, accessed from http://index.hu/bulvar/aut4289/ on May 15, 2009).

Kidder, J. L. (2006) 'Bike Messengers in a Global City: An Exploration of Structure and Agency'. Paper presented at the annual meeting of the American Sociological Association, Montreal Convention Center, Montreal, Quebec, Canada (Electronic document, accessed from http://www. allacademic.com/meta/p96572_index.html on May 15, 2009).

Larsson, M. (2004) 'Political Action in a Post-Socialist Society. An Anthropological Analysis of the Hungarian Telecottage Movement', (Electronic document, accessed from http: //www. anthrobase.com/Txt/L/Larsson_M_02.htm on May 15, 2009).

Lefebvre, H. (1991) The Production of Space (Oxford: Wiley-Blackwell).

Lefebvre, H. (1996) Writings on Cities (Oxford: Blackwell).

Low, S. M. (1996) 'Spatializing Culture: The Social Production and Social Construction of Public Space in Costa Rica', American Ethnologist, Vol. 23, No. 4, 861-879.

Low, S. M. (2003) 'Embodied Space(s): Anthropological Theories of Body, Space, and Culture', Space and Culture, Vol. 6, No. 9, 9-18.

Martin, R. (1990) Performance as Political Act: The Embodied Self (New York: Bergin \& Garvey).

Mitchell, D. (1995) 'The End of Public Space? People's Park, Definitions of the Public, and Democracy', Annals of the Association of American Geographers, Vol. 85, No. 1, 108-133.

Mitchell, D. (2003) The Right to the City. Social Justice and the Fight for Public Space (New York: The Guilford Press).

Pickvance, K. (2000) 'The Diversity of Eastern European Social Movements', in P. Hamel, H. Lustiger-Thale and M. Mayer (eds) Urban Movements in a Globalising World (London-New York: Routledge). 192-212.

della Porta, D. (1996) 'Social Movements and the State: Thoughts on the Policing of Protest', in D. McAdam, J. D. McCarthy and M. N. Zald (eds) Comparative Perspectives on Social Movements. Political Opportunities, Mobilizing Structures, and Cultural Framing (Cambridge: Cambridge University Press). 62-92.

della Porta, D. - Diani, M. (1991) Social Movements. An Introduction (Oxford: Blackwell).

Sibley, D. (1995) Geographies of Exclusion (New York: Routledge).

Sorkin, M. (1999) 'Introduction. Traffic in Democracy', in J. Copjec and M. Sorkin (eds) Giving Ground. The Politics of Propinquity (New York: Verso). 2-15.

Strauss, A. (2008) Qualitative Analysis for Social Scientists (Cambridge: Cambridge University Press).

Switzky, J. (2002) 'Riding to See' in C. Carlsson (ed.) Critical Mass. Bicycling's Defiant Celebration (Edinburgh: AK Press). 186-192.

Tax, S. (1964) 'The Uses of Anthropology', in S. Tax (ed.) Horizons of Anthropology (Chicago: Aldine). 248-58.

Tordai, Zs. (2008) 'Kritikus tömegek kétkeréken és online. Társadalmi mozgalom- és internetes közösségszervezés a magyar Critical Mass példáján’ (Budapesti Corvinus Egyetem Szociológia és Társadalompolitika Intézet) (Thesis for Corvinus University, Manuscript).

White, T. (2002) 'Reels on Wheels', in C. Carlsson (ed.) Critical Mass. Bicycling's Defiant Celebration (Edinburgh: AK Press). 145-132. 
